\title{
PREVENTION OF MOTHER-TO-CHILD TRANSMISSION OUTCOMES IN THE PRIVATE SECTOR IN CENTRAL DURBAN
}

\author{
Shakira M Cassim, MB ChB, DCH (SA) FCPaed (SA), MPH, Dip HIV Man (SA) \\ Julia H Botha, BPharm, PhD \\ Department of Therapeutics and Medicines Management, Nelson R Mandela School of Medicine, Durban
}

\begin{abstract}
The prevention of mother-to-child transmission (PMTCT) programme in the central region of Ethekweni Metro, KwaZulu-Natal (Durban central area), was investigated. Data for all HIV-exposed infants from eight private paediatric practices seen between January 2004 and June 2005 were reviewed retrospectively. One hundred and one black African infants were born to $100 \mathrm{HIV}$-positive women of average age 30 years. Median viral loads and CD4 counts were 11391 copies/ml and 426 cells/ $\mu$, respectively. Eighty-six women received HAART and 5 had no prophylaxis. Of the 92 infants tested, 2 were HIV positive, giving a transmission rate of $2.2 \%$. Both their mothers had received suboptimal prophylaxis, and if they are excluded, the transmission rate falls to less than $1 \%$, a rate consistent with those in the developed world.
\end{abstract}

Effective prevention of mother-to-child transmission (PMTCT) strategies are known to reduce the incidence of paediatric HIV infection. ${ }^{1}$ A small non-governmental project at McCord Hospital in Durban, KwaZulu-Natal, with access to highly active antiretroviral therapy (HAART), reported vertical transmission of $2.9 \%$. The authors of that paper also reported results of two studies in the public sector, in 2002 and 2006, respectively, where transmission rates of $8.7 \%$ and 20.8\% were achieved with a PMTCT drug regimen comprising single-dose nevirapine (sdNVP). ${ }^{2}$ These were in Gauteng and KwaZulu-Natal respectively, while in the Western Cape in 2003 a rate of $8.8 \%$ was recorded for women given dual therapy of zidovudine (ZDV) from 34 weeks and sdNVP. ${ }^{3}$

In the private sector, many patients belong to medical scheme-funded disease management programmes, such as Aid for AIDS (AfA). PMTCT guidelines for developed countries, where HIV-infected newborns are becoming uncommon, are followed. ${ }^{1{ }^{14}}$ The programme comprises prenatal HIV-1 counselling and testing, and HAART (irrespective of CD4 count) from the second trimester onwards, unless the mother is already on antiretrovirals or fulfils the criteria for starting HAART immediately. Elective caesarean section, together with intrapartum intravenous ZDV, is offered and ZDV is given to the neonate. Formula feeding is supplied for 6 months and breastfeeding is avoided.

While many private practitioners follow AfA guidelines, they may use different regimens, depending on cost considerations. The present study aimed to investigate the outcome of infants born to HIV-positive mothers managed in a group of private paediatric practices in central Durban, KwaZulu-Natal.

\section{METHODS}

Ethical approval for this retrospective chart review was obtained from the Biomedical Research Ethics Committee of the Nelson R Mandela School of Medicine (Reference number BE047/47). Of the 20 paediatricians in the Durban Central region, 4 (20\%) did not respond. All charts of HIV-exposed infants born between January 2004 and June 2005, from the 8 paediatricians who agreed to participate, were included. Data were collected by means of previously piloted questionnaires.

\section{RESULTS}

One hundred and one charts were available, of which 50 came from a single practice (which is an HIV referral centre). The balance was contributed approximately equally by the remaining practitioners.

One hundred and one infants (one set of twins) were delivered to 100 black African women, 93 by caesarean section. Fifty infants were boys, 20 were low birth weight, 2 were large for gestational age and 79 were appropriate for gestational age. Ninety-seven mothers were medical scheme beneficiaries (86 contracted to AfA). The mean age was 30 (range 18 - 44) years and mean parity was 1 child (range 1 - 4). Presentation and antenatal care initiation were in the first, second 
and third trimesters for 40\%, 34\% and 26\% of mothers, respectively. HIV infection had been diagnosed in the current pregnancy in the majority (75\%) of cases, and the rest already knew their status.

Viral load and CD4 count measurements were recorded for 86 and 91 women, respectively. The median CD4 count was 426 (intraquartile range (IOR) 244 - 613) cells/ $/ \mu$. Only $13 \%$ of the women had CD4 counts less than 200 cells/ $/$ l. The median viral load at first presentation was 3.97 (IOR 1.6 - 5.8) logs or 11391 (IQR 2013 - 41 502) copies/ml.

Eighty-six women (86.0\%) received HAART. This comprised ZDV and lamivudine (3TC), either together with lopinavir/ritonavir (if the CD4 count was >250) or together with NVP if the CD4 count was $<250$. The regimen also included intrapartum intravenous ZDV. Nine women did not receive HAART; 7 received only intrapartum intravenous ZDV, 1 had only intrapartum NVP, and 1 had dual therapy with ZDV/3TC. Treatment was initiated at less than 28 weeks in 32 women and between 28 and 34 weeks in 41 women. Five women received no prophylaxis because they presented for antenatal care very late in the third trimester.

All infants were formula fed and received ZDV for 6 weeks. Haemoglobin $(\mathrm{Hb})$ measurements in 98 patients revealed 18 (4 preterm) with anaemia. Seventy-nine infants received PCP prophylaxis. There were 18 preterm infants, half of whom were born to women with low CD4 counts who received NVP as part of their HAART. Five and 3 of the premature infants were born to mothers who had received protease inhibitors and no prophylaxis, respectively. One of the latter 3 seroconverted.

Eight infants defaulted follow-up and 1 died (of unknown cause) at 5 weeks before testing was possible. Ninetytwo infants were tested, 61 of them by polymerase chain reaction (PCR) at 6 weeks. Fifty-six were tested by enzyme-linked immunosorbent assay (ELISA) at 18 months (some of whom had already had a first PCR). Two infants were diagnosed positive, and their details are set out in Table I.

\section{DISCUSSION}

Although our transmission rate of $2.2 \%$ appears better than the $2.9 \%$ from the McCord experience, the proportions of women in that group with low CD4 counts and receiving HAART were double and half, respectively. Our rate was not as good as the situation that pertains in the USA and Europe, where HIV-infected newborns are becoming uncommon, but is close to the
TABLE I. DETAILS OF THE 2 HIV-POSITIVE INFANTS

\begin{tabular}{|c|c|c|}
\hline & Infant 1 & Infant 2 \\
\hline Birth weight $(\mathrm{kg})$ & 2.2 & 3.0 \\
\hline $\begin{array}{l}\text { Gestational age } \\
\text { (wks) }\end{array}$ & 33 & 38 \\
\hline Health at birth & $\begin{array}{l}\text { Congenital } \\
\text { pneumonia, } \\
\text { anaemia }\end{array}$ & Well \\
\hline \multirow[t]{2}{*}{ Treatment } & ZDV for 6 weeks & ZDV for 6 weeks \\
\hline & Mother 1 & Mother 2 \\
\hline Age (yrs) & 28 & 37 \\
\hline Mode of delivery & Caesarean section & Caesarean section \\
\hline Diagnosis of HIV & $2-3$ years earlier & $\begin{array}{l}\text { During current } \\
\text { pregnancy }\end{array}$ \\
\hline ART prophylaxis & None & $\begin{array}{l}\text { HAART initiated } \\
5 \text { days before } \\
\text { delivery }\end{array}$ \\
\hline Intrapartum IV ZDV & Yes & Yes \\
\hline $\begin{array}{l}\text { Viral load at } \\
\text { delivery }\end{array}$ & Not recorded & $\begin{array}{l}50000 \\
\text { copies } / \mathrm{ml}\end{array}$ \\
\hline CD4 count at delivery & Not recorded & 327 cells/ $\mu \mathrm{l}$ \\
\hline
\end{tabular}

1 - 2\% transmission expected for women from socioeconomically advantaged areas in Africa who can safely formula feed. ${ }^{1}$

The mothers of both positive infants had suboptimal PMTCT, and if these women are excluded the transmission rate falls to less than 1\%. In fact, in those women who were fully compliant there was no transmission.

One of the 2 mothers had been diagnosed 2 years before the pregnancy and presented for antenatal care but was not on medical aid and could not afford HAART. It had been planned to initiate HAART at 34 weeks, but she went into labour at 33 weeks. The other mother was diagnosed early in the current pregnancy but did not return for results, so HAART was initiated only 5 days before delivery. Non-adherence is a risk factor in perinatal transmission, but it is a problem with which even a developed country like the UK is grappling. ${ }^{5}$

Our study has confirmed the success of an appropriate PMTCT programme and the importance of prophylaxis and adhering to the protocol.

\section{REFERENCES}

1. Coovadia HM. Perspectives on paediatric HIV/AIDS: Prevention of mother to child transmission of HIV. Current Science 2008; 95(9): 1133-1149.

2. Geddes $R$, Knight $S$, Reid $S$, Giddy J, Esterhuizen $T$, Roberts $C$. Prevention of mother-to-child transmission of HIV programme: low vertical transmission in KwaZulu-Natal, South Africa. S Afr Med J 2008; 98: 458-462.

3. Draper B, Abdullah F. A review of the prevention of mother-to-child transmission program of the Western Cape provincial government 2003-2004. S Afr Med J 2008; 98: 431-434.

4. Regensberg L, Makiwane M. AfA Clinical Guidelines. 7th ed. Pinelands: Aid for AIDS; 2009. http://www.aidforaids.co.za/EX_Medscheme_VS07/Documents/ AFA/Guidelines_book_Final.pdf (accessed 30 May 2009).

5. Kingston MA, Letham $\mathrm{CJ}$, McQuillan 0 . Adherence to antiretroviral therapy in pregnancy. Int J STD AIDS 2007; 18(11): 787-789. 